\title{
Психологічна корекція як складова санаторно- курортної реабілітації дітей в періоді ремісії онкогематологічних захворювань
}

\author{
Шаповалова Г. А. \\ Одеський національний медичний університет, м. Одеса, Україна
}

Актуальність. За даними літератури, психотравмуючий вплив онкозахворювання негативно впливає на психологічний стан дитини та ї̈ сім'ї в цілому. Тому психологічну корекцію таких дітей та їх батьків слід визнати важливою складовою санаторнокурортної реабілітації.

Мета роботи полягала у дослідженні динаміки психологічного стану дітей в періоді ремісії онкогематологічних захворювань (ОГЗ) в комплексі санаторно-курортної реабілітації.

Матеріали та методи. Автором у співпраці 3 дитячим психологом проведена діагностика психологічного стану 30 дітей (18 хлопчиків і 12 дівчаток у віці 5-15 років) та іх батьків в умовах санаторно-курортної реабілітації (санаторій ім. Чкалова, м. Одеса). Переважною формою ОГЗ був гострий лімфобластний лейкоз (60,6\%). У дітей застосовували анкету 3 виявлення тривожності; запам'ятовування 10 слів; «Коректурну пробу» (літерний варіант). Для психодіагностики батьків використовували коротку шкалу тривоги, депресії і постстресових розладів (Б. Харт); опитувальник депресивності Бека; шкалу тривожності Гамільтона. Програма корекційних занять (упродовж 21 дня, двічі на тиждень) включала малювання (фарби, фарби + нитки, фарби + руки, штрихування крейдами, монотипія + кляксогра- фія) і музикотерапія (малювання під музику, ігри під музику, вправи на релаксацію).

Результати дослідження та їх обговорення. Ефективність корекційних занять проявлялась у зменшенні кількості дітей 3 високим (від 42,3 до 6,66\%) та відповідним збільшенням групи дітей із середнім (до $63,3 \%$ ) рівнем тривожності. Оцінка рівня довільного запам'ятовування показала зменшення низького рівня до $10 \%$, підвищення середнього - до $33,3 \%$, високого - до $56,6 \%$ дітей. За результатами коректурної проби спостерігалось зниження кількості дітей 3 порушенням концентрації (від 73,3 до 53,3\%), обсягу (від 56,6 до 36,6\%), переключення (від 50 до $30 \%$ ) уваги. У $70 \%$ батьків була задоволена потреба у психологічній допомозі, у 83,4\% зникли депресивні симптоми, у $50 \%$ - тривожні стани.

Висновок. Психологічна корекція онкохворих дітей сприяє покращенню їх соціальної адаптації та психоемоційного стану. Психологічна допомога батькам таких дітей зменшує прояви особистісної та реактивної тривожності.

Перспективи подальших досліджень. Доцільно продовжувати дослідження щодо психологічної корекції онкохворих дітей за іншими методами.

Ключові слова: діти, онкогематологічні захворювання, психологічна корекція. 